DOI https://doi.org/10.30525/978-9934-26-148-0-7

\title{
ШЛЯХИ ФОРМУВАННЯ ПРАВОВОЇ ДЕРЖАВИ В УКРАЇНІ
}

\author{
Кравцова М. О. \\ кандидатка юридичних наук, \\ дочентка кафедри загальноправових дисииплін \\ Донеиького державного університету внутрішніх справ \\ м. Маріуполь, Донецька область, Україна
}

\section{Приходько А. А.}

кандидат юридичних наук, капітан поліції, старший викладач кафедри організаиії досудового розслідування Факультету № 1 Криворізького навчально-наукового інституту Донецького державного університету внутрішніх справ м. Кривий Ріг, Дніпропетровська область, Украӥна

У сучасній зарубіжній юридичній i політологічній літературі точаться суперечки про сутність і функції правової держави. Серед вчених, які обговорюють ці проблеми, знаходяться навіть такі, які закликають взагалі відмовитися від ідеї правової держави, вважаючи, що вона вже давно виконала своє призначення і свої соціальні та економічні функції. Інші ж виступають за подальше забезпечення розвитку правової державності, але на сучасних принципах його побудови. Однозначного розуміння сутності і функцій правової держави не можна знайти і в сучасній вітчизняній юридичній науці.

Слід зазначити, що правова держава - це держава, в якій правовими засобами реально забезпечені права і свободи людини і громадянина, $\mathrm{i}$ вся публічно-політична діяльність держави здійснюється в суворій відповідності з правом і законом. Це накладає свій специфічний відбиток на теорію і практику формування правової державності в Україні. При цьому ми виходимо з того, що Конституція України проголошує Україну як правову державу (ст. 1ч. 1) [3]. Однак це зовсім не означає, що у нас вже склалася правова держава в повному розумінні цього слова. До того ж правова держава - це аксіома і має базуватися на розвиненому громадянському суспільстві. Ми ж знаходимося тільки на самому початку шляху.

Маменко Б. М., Пархоменко-Куцевіл О. І. зазначають, що «до складових правової держави можна віднести створення національної концепції правової держави, іiі модернізація внаслідок соціальних 
викликів» [4, с. 104]. Важливим елементом правової держави є надійний захист прав і свобод людини та громадянина [6, с. 36].

Розвиток правової держави - це складний і тривалий процес, який триватиме у міру проведення в життя реформ, загальнолюдських цінностей побудови сучасного демократичного суспільства. Проведення в державі різних реформ можна вважати необхідною передумовою остаточного формування правової держави.

Під правовою державою розуміється така держава, яка в своїй роботі керується вимогами тільки правових приписів, основ, а не діє відповідно до інтересів політичної еліти, олігархів і транснаціональних корпорацій, які б лобіювали свої інтереси в процесі реалізації державними органами їх функцій, не під впливом ситуації, в певний момент популістської кон'юнктури, особливо передвиборної, і тим більше не під впливом корумпованих чиновників i злочинних співтовариств. Ідея правової держави була актуальною і в минулому. Основний привід такої уваги до правової держави полягає не тільки в гуманізмі самої ідеї його виникнення, але і в пошуках шляхів їі найбільш доцільного оформлення і ефективного здійснення.

При вивченні прогалин правової держави слід розглядати виникаючі питання як з позиції норми права, так і з точки зору справедливості дій держави. На початку 90-х років почався активний рух становлення правової держави, в той час як досвід еволюційного розвитку політичних інститутів і держави, а також поступове зміцнення правової бази правової держави - практично були відсутні [4]. Варто виділити найбільш відомі проблеми, які перешкоджають розвитку правової держави: нерозвиненість громадянського суспільства, недотримання автономії місцевого самоврядування; правовий нігілізм, повільний розвиток ринкового господарства, що не дає свободу підприємництву; незабезпечення рівності громадян перед законом і судом, які прописані на папері; порушення виборчих прав громадян, фальсифікації, спотворення правосвідомості.

Історичний шлях нашої держави показує, що в історії України виявляються проблеми перспективного розвитку громадянської культури i цивільних інститутів. В Україні на всіх етапах свого існування прагнули придушити будь-які прояви автономії особистості i суспільства. Громадянське суспільство ще знаходиться на стадії розвитку, характерна нестабільність суспільних відносин, його структура аморфна.

Проблему спотворення правосвідомості, тобто психічного відображення людиною державно-правової дійсності у вигляді громадських понять і образів, варто долати. Деформація правосвідомості ж являє собою спотворення психічного відображення людиною державно-правової дійсності у вигляді узагальнених понять і образів, їх неправильне 
розуміння чи заперечення [1]. Деформація правосвідомості в будь-якому суспільстві $є$ найсильнішим чинником, що негативно впливає на процес побудови правового громадянського суспільства. Тому усунення дефектів правосвідомості $є$ одним 3 найважливіших напрямків діяльності будь-якого сучасної держави. Говорячи про проблеми в правовій культурі, варто відзначити, що якщо вона нерозвинена, знаходиться на низькому рівні, державні і правові інститути заперечуються більшістю членів суспільства як цінність. Суспільні відносини регулюються іншими, позаправових і позадержавних засобами. В даному випадку необхідно розуміти, що правова культура не може бути ізольована від загальної культури суспільства. Не може бути в некультурного суспільстві високої правової культури, і навпаки, в культурному, цивілізованому суспільстві не може бути низької правової культури. Касинюк Л.А., Мельник Е.А. в своїй статті зазаначають, що важливим чинником також є правова культура правлячої еліти [1, с.31].

Однією 3 найбільш головних проблем розвитку правової держави $\epsilon$ грубе порушення в країні принципу верховенства права (поняття верховенства права було введене Дайсі А. В. у 1885 році) [5]. Значна частина норм, закріплена державним законодавством, не реалізується, діє лише формально. Держава не завжди виявляється здатною забезпечити права і свободи громадян в різних сферах життєдіяльності. Принцип поділу влади в Конституції України показує, що законодавча влада не здатна в повній мірі організовувати державний контроль за виконавчою владою щодо забезпечення реалізації державних законів. Успішне вирішення даної проблеми допоможе створити сприятливий грунт для створення правової держави. Необхідно досягати високого рівня правового і політичної свідомості: створення несуперечливого законодавства, розвиток загальної культури і правової,

Отже, розвиток правової держави - складний і повний помилок процес. Реалізовувати ці цілі потрібно поетапно і грамотно, з урахуванням історичних та національних особливостей країни. Необхідно максимально використовувати вже накопичений досвід інших країн щодо здійснення правових реформ, посилено розвиваючи рівень продуктивних сил і правової свідомості громадян України. Правову державу побудувати за пару років або навіть десятків років неможливо. В інших країнах це явище протікало довго, протягом століть, поступово удосконалювалося. Варто долати ці перешкоди, активно здійснювати свої конституційні виборчі права, брати участь в політичному житті країни, заявляти про свої права.

\section{Література:}

1. Калиновський Ю. Ю. Правосвідомість українського суспільства: генеза та сучасність : монографія. Харків : Право, 2008. 288 с. 
2. Касинюк Л.А., Мельник Е.А. Правова держава та проблеми становлення її в україні. Юридичний науковий електронний журнал. 2019. № 6. C. 28-32.

3. Конституція України. Відомості Верховної Ради України. 1996, № 30, ст. 141. URL: https://zakon.rada.gov.ua/

4. Маменко Б. М., Пархоменко-Куцевіл О. І. Передумови, ознаки і шляхи формування правової держави. Інвестиції: практика та досвід. 2021. № 17. С. 99-105.

5. Малишев Б.В. Принципи панування права (the rule of law) у праці Альберта Дайсі «Вступ до вивчення конституційного права». Проблеми філософії права. 2008. T. VI-VII. C. 118-123.

6. Чукаєва В. О. Громадянське суспільство та конституційна доктрина розвитку правової держави україни. Актуальні проблеми вітчизняної юриспруденції. 2019. № 3. С. 36-38.

DOI https://doi.org/10.30525/978-9934-26-148-0-8

\section{НАСИЛИЕ И ВЛАСТЬ: ПРОБЛЕМА КОНТРОЛЯ}

\section{Леонов Б. Д.}

доктор юридических наук, старший научный сотрудник, профессор кафедры права

Международного классического университета имени Пилипа Орлика

\section{Исмайлова А. И.}

соискатель высшего образования II курса обучения спечиальности 081 Право

Международного классического университета имени Пилипа Орлика г. Николаев, Украина

Классическая постановка вопроса о власти заключается в том, что она представляет собой совокупность политических институтов, посредством функционирования которых одни социальные группы получают возможность навязывать свою волю другим и действовать в соответствии с так называемыми общими (общенародными, общегосударственными) интересами [1, с. 273].

Изначально создание государства обуславливается потребностью политической организации власти народа. Однако, как справедливо отмечает В.Ф.Антипенко, из реального обладателя такой власти, «держателя» нации, гаранта ее целостности и безопасности оно в силу 